\title{
Nutrient Cycling in Corymbia citriodora in the State of Rio de Janeiro, Brazil
}

\author{
Gláucio Mello Cunha ${ }^{1}$ (D), Antonio Carlos Gama-Rodrigues ${ }^{2}$ (D), \\ Emanuela Forestieri Gama-Rodrigues $^{2}$ (D), Gisele Rodrigues Moreira ${ }^{1}$ \\ ${ }^{1}$ Universidade Federal do Espirito Santo - UFES, Alegre/ES, Brasil \\ ${ }^{2}$ Universidade Estadual do Norte Fluminense Darcy Ribeiro - UENF, Campos do Goytacazes/RJ, Brasil
}

\begin{abstract}
The quantification and transfer of nutrient stock among compartments in the forest environment is the key to understanding the nutrient cycling process. The aim of this study was to quantify the nutrient stock and dynamics by litter deposition in a Corymbia citriodora settlement in the Mountainous region of the State of Rio de Janeiro. Different plant parts, deciduous material and litter were chemically analyzed for nutrients. The biomass of trees was $127.23 \mathrm{Mg} \mathrm{ha}^{-1}$, making up about $85.8 \%$ of the nutrient stock. On average, the nutrient flux represented $13.6 \%$ of nutrients stored in the biomass above the soil. The nutrient cycling process involving $\mathrm{N}, \mathrm{P}, \mathrm{K} \mathrm{Ca}$, and $\mathrm{Mg}$ in the long-rotation Corymbia citriodora crop represents an important strategy for maintaining productivity of the forest site.
\end{abstract}

Keywords: litter, eucalyptus, nutrient stock, forest sustainability. 


\section{INTRODUCTION}

Corymbia citriodora (Hook.), K. D. Hill, \& L. A. S. Johnson, widely known as eucalyptus citriodora, is a multi-use tree species. Recently, the use of this species has become very widespread and appreciated by loggers for industrial and furniture purposes due to the shortage of certified wood (Vilas Bôas et al., 2009). This is because eucalyptus citriodora wood has shown to be durable and little susceptible to cracking. In this respect, this species differs from other eucalyptus species that are usually grown in short cycles for cellulose, ceramics, coal, civil construction, etc. Moreover, extensive $C$. citriodora plantations are not common and rather have long cycle. This also partly explains why scientific studies for this species are scarce.

In the State of Rio de Janeiro, homogeneous forest plantations occupy 18,426 ha, and eucalyptus represents $97.9 \%$ of this total. It is the second largest mountain region of the state, regarding this species. It comprises $21.4 \%$ of the total cultivation area, with predominance in small- and medium-size rural properties (Amorim et al., 2012). In this sense, the state of Rio de Janeiro, in relation to other states of the federation, presents one of the smallest areas planted with eucalyptus in Brazil (IBGE, 2014), which makes it a major importer of this raw material. Therefore, evaluating the behavior of eucalyptus species, $C$. citriodora is an alternative for land use of great relevance as source of information for the state of Rio de Janeiro.

The first studies addressing some nutrient cycling aspects in C. citriodora in Brazil, were carried out by Rocha et al. (1978), and biomass production and nutrient export were studied by Pereira et al. (1984). Recently, several studies have evaluated nutrient cycling in eucalyptus for issues related to production sustainability in short cycles (Cunha et al., 2005; Laclau et al., 2010; Diniz et al., 2011; Viera et al., 2014b).

Nutrient cycling in eucalyptus stands allows the evaluation of possible changes in applied management techniques. Nutrient cycling also makes it possible to infer about the sustainability of plantations. In low-fertility soils, nutrient accumulation and distribution can serve as indicators of nutrient availability for plants (Reis \& Barros, 1990; Gama-Rodrigues et al., 2008). Studies of this type could also provide support for the development of management techniques that are ecologically and economically feasible.

Sustained timber production such as eucalyptus depends on how the crop is harvested (Santana et al. 2008; Paes et al., 2013). In total harvest, where all tree parts are harvested from the area, higher nutrient content is exported from the system than when harvesting only the trunk or part of it (Santana et al., 2008). Natural ecosystems have served in many works as reference for various agricultural and forestry systems (Fonseca et al., 1993; Drumond et al., 1997). References regarding the size of the nutrient reservoir accumulated by litter of different forest allow inferring about the quality of the stored material and its decomposition rate. C. citriodora species, in relation to the natural forest, accumulates larger amount of litter, which would probably reflect the quality of the stored material. This results in lower decomposition rate, considering $\mathrm{C} / \mathrm{N}$ ratio of 50 for eucalyptus litter and 25 for natural forest (Fonseca et al., 1993).

The aim of this study was to quantify the nutrient stock of a Corymbia citriodora stand and its nutrient dynamics by litter deposition throughout the year in the mountainous region of the state of Rio de Janeiro.

\section{MATERIAL AND METHODS}

The eucalyptus crop under study (Corymbia citriodora), implanted in 1984, has current density of 1453 trees ha-1 $^{-1}$ with $3 \times 2 \mathrm{~m}$ plant spacing. The initial purpose of the crop was to produce essential oil, but it has not yet been used for this purpose. The forest is located in the municipality of Santa Maria Madalena, a mountain region of the state of Rio de Janeiro, with geographical coordinates of $21^{\circ} 52^{\prime} 4^{\prime \prime} \mathrm{S}$ and $41^{\circ} 58^{\prime} 33^{\prime \prime} \mathrm{W}$., according to data obtained from São Fidélis, Santa Maria Madalena, and Macabuzinho stations, the climate is dry sub-humid tropical, with heat being well distributed throughout the year. Rainfall during the study development is presented in Figure 1.

Three $25 \times 20 \mathrm{~m}$ plots were marked, in which litter collectors were installed. This featured a ratio of five collectors (1m x 1m) per plot made of wood and nylon screens with $1 \mathrm{~mm}$ mesh opening.

In the three study plots, all trees of each plot were measured at eight of $1.30 \mathrm{~m}$ in order to obtain the diameter at breast height $(\mathrm{DBH})$. With the aid of 
laser hypsometer, the height of trees was estimated. The measured trees were arranged into 4 diametric classes with the following frequency: $\mathrm{DBH} 9-12 \mathrm{~cm}$ 22.38\%; DBH 12, 1-15 cm 56.72\%; DBH 15, 1-18 cm $16.42 \%$, and $\mathrm{DBH} 18-21 \mathrm{~cm} 4.48 \%$. On average, the mortality rate was $19 \%$.

The soil of the area was classified as Dystrophic Red-Yellow Latosol with attributes presented in Table 1.

Litter production was quantified every 30 days. For this, the material collected was air-dried and then separated into leaves, branches smaller than $2 \mathrm{~cm}$ in diameter, flowers and fruits, bark, and other materials that were difficult to categorize as a function of size. The material separated from each collector (leaf, branch, bark, reproductive structures, and fine residue) was dried at $70^{\circ} \mathrm{C}$ in an air circulation oven until reaching constant weight. Samples were weighed until they no longer presented mass variation in the last weighing.

The chemical analyses of litter were carried out in all fractions separately. The five collectors of each plot composed simple samples that were mixed and became a composite sample.

The litter accumulated on soil was collected in the winter and summer periods using a wood template measuring $0.5 \mathrm{~m}$ x $0.5 \mathrm{~m}$. Each plot was represented by 4 simple samples, which together formed a composite sample. The collected material was dried in oven at temperature of $70^{\circ} \mathrm{C}$ until reaching constant weight.

In plots, the biomass of shoot components was quantified as follows: From measurements of DBH and height of all trees of each plot, the mean height and the mean $\mathrm{DBH}$ of the population of 84 trees were calculated. Thus, two trees with $\mathrm{DBH}$ and height equal to the mean value of the population were selected for biomass measurement, as similarly performed by Pereira et al. (1984), Teixeira et al. (1989), Santana et al.(2008), and Gatto et al. (2014). Trees were harvested and, then, measured to obtain volume by the Smalian method. With the aid of a chainsaw, stems were sectioned into pieces of $1 \mathrm{~m}$ in length. Discs were then removed to estimate dry matter content and to obtain samples for chemical analyses. At this point, the fresh biomass of leaves, thin branches, bark, and wood was also obtained. Samples were taken to the laboratory to obtain dry matter after drying to constant weight at $70{ }^{\circ} \mathrm{C}$, in order to correct the fresh biomass and to estimate biomass per ha. Biomass estimation by area was obtained by multiplying the average biomass of felled trees by the number of trees in each plot.

All plant material was ground in a Wiley mill, from which a duplicate sub-sample was removed for nitro-perchloric digestion for $\mathrm{P}, \mathrm{K}, \mathrm{Ca}$, and $\mathrm{Mg}$ determination. Another

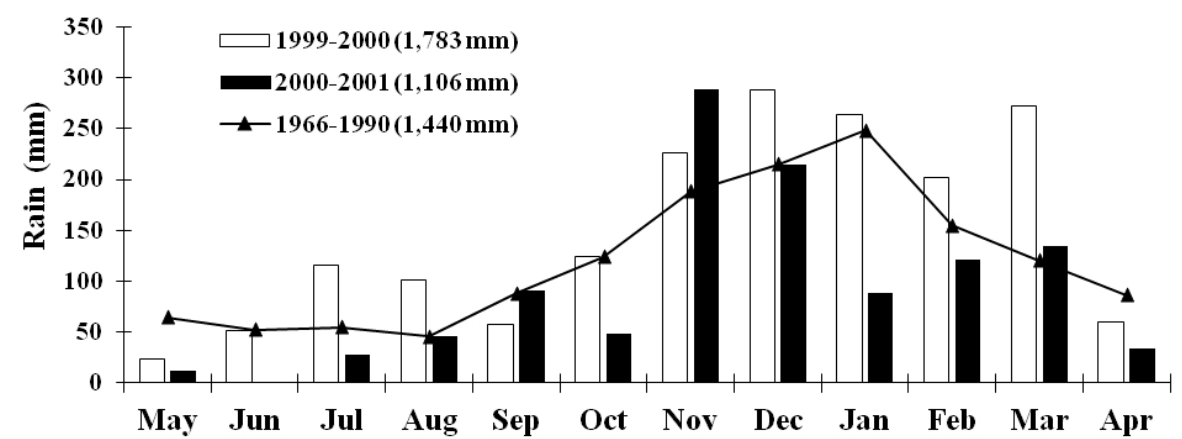

Figure 1. Monthly rainfall in Santa Maria Madalena, RJ, Brazil $21^{\circ} 37^{\prime} \mathrm{S}, 42^{\circ} 05^{\prime} \mathrm{W}$ (unpublished data provided by Instituto Nacional de Meteorologia - INMET).

Table 1. Chemical characteristics of soil on eucalyptus plantation (Corymbia citriodora) in the state of Rio de Janeiro, Brazil.

\begin{tabular}{|c|c|c|c|c|c|c|c|c|}
\hline Depth & \multirow{2}{*}{ pH } & C & $\mathbf{P}$ & $\mathbf{K}$ & $\mathrm{Ca}$ & Mg & Al & $\mathrm{H}+\mathrm{Al}$ \\
\hline $\mathrm{cm}$ & & $\mathrm{g} \mathrm{kg}^{-1}$ & \multicolumn{2}{|c|}{$\mathrm{Mg} \mathrm{kg}^{-1}$} & \multicolumn{4}{|c|}{$-\mathrm{cmol} \mathrm{kg}^{-1} \longrightarrow$} \\
\hline $0-5$ & 4.50 & 20.9 & 5.7 & 174 & 1.82 & 1.59 & 0.27 & 6.61 \\
\hline $5-10$ & 4.31 & $17.5 \mathrm{~b}$ & 5.1 & 122 & 1.10 & 1.33 & 0.46 & 5.80 \\
\hline
\end{tabular}


duplicate sub-sample was removed for sulfuric digestion for $\mathrm{N}$ determination by the Kjeldahl method, (Tedesco et al., 1985). After digestion, K was determined by flame photometry, $\mathrm{P}$ was colorimetrically determined after reduction of the phosphomolybdic complex, and ascorbic acid, $\mathrm{Ca}$, and $\mathrm{Mg}$ were determined by atomic absorption. $\mathrm{C}$ was determined by wet digestion using a $0.200 \mathrm{~g}$ plant material sample (Anderson \& Ingram, 1996).

Soil fertility characterization was followed by the sampling of 15 single samples/composite samples at depths of $0-5$ and $5-10 \mathrm{~cm}$. The plot was represented by four composite samples.

$\mathrm{K}$ (flame photometry) and $\mathrm{P}$ (colorimetrically) concentrations were determined after extraction with Mehlich-1. Ca and Mg (atomic absorption spectrophotometry) were determined after extraction with $\mathrm{KCl} 1 \mathrm{M} \mathrm{L}^{-1}, \mathrm{~N}$ and $\mathrm{pH}$ in water, $\mathrm{Al}$ and $\mathrm{H}+\mathrm{Al}$ and organic carbon, according to EMBRAPA (1997).

To calculate the nutrient concentration variation in leaves, the following terms were designated: canopy leaves (cl) (those collected after the harvest of trees), leaf fall litter (ll) (obtained by the collector), and forest floor leaf litter (lf) (obtained by collecting litter accumulated on the soil).

The nutrient content per area was determined by multiplying the concentration of nutrients in the various components of trees by biomass per area.

To estimate the decomposition rate $\left(\mathrm{K}_{\mathrm{L}}\right)$, the annual leaf litter production and the average leaf litter layer value were estimated: $\mathrm{K}_{\mathrm{L}}$ = annual leaf litter production / forest floor leaf litter (Olson, 1963). In the estimation of the mineralization rate $\left(\mathrm{K}_{\mathrm{E}}\right)$, the annual average nutrient intake of the leaf fall litter produced and the average annual nutrient stock of the forest floor leaf litter mass were considered: $\mathrm{K}_{\mathrm{E}}=$ nutrient supply / nutrient stock intake.

Data were evaluated by descriptive statistics, obtaining means, standard error, confidence interval, and standard deviations of means.

\section{RESULTS AND DISCUSSION}

The estimated C. citriodora biomass was $127.23 \mathrm{Mgha}^{-1}$ $( \pm 10.39)$, distributed into wood $\left(87.42 \mathrm{Mg} \mathrm{ha}^{-1}\right)$, bark (24.53 $\left.\mathrm{Mg} \mathrm{ha}^{-1}\right)$, branches (12.28 $\mathrm{Mg} \mathrm{ha}^{-1}$ ), and leaves $\left(3.00 \mathrm{Mg} \mathrm{ha}^{-1}\right)$. This represented $72 \%$ of the C. citriodora biomass estimated by Pereira et al. (1984) in in the same spacing, presenting $177.34 \mathrm{Mg} \mathrm{ha}^{-1}$ nine years after planting. The mean diameter (DBH) of trees was

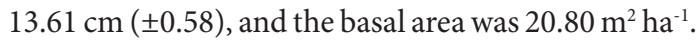
In a C. citriodora settlement in the state of São Paulo, Vilas-Bôas et al. (2009) found DBH and basal area of $12.5 \mathrm{~cm}$ and $20.7 \mathrm{~m}^{2} \mathrm{ha}^{-1}$, respectively, after 8 years of development in $3 \times 2 \mathrm{~m}$ spacing, while Pereira et al. (1984) obtained DBH of $14 \mathrm{~cm}$ at 9 years of age with the same planting density. Likely, climatic limitations such as water deficiency that are common in the lower slopes of the Serra do Mar, a northern part of the State of Rio de Janeiro where there are dry times (Sant'Anna, 2005), in addition to genetic material from seeds that may cause lower yields in eucalyptus (Ferreira, 1992). Probably, climatic limitations such as water deficiency, common in the western slopes of Serra do Mar, as in the northern part of the State of Rio de Janeiro, where dry islands or rain shadows are observed (Sant'Anna, $2005)$ and/or genetic material from seeds may cause less eucalyptus productivity. Santana et al. (2008) estimated lower productivity in eucalyptus forest sites located in regions with water deficits, compared to regions with higher water availability.

Wood biomass accumulated most of nutrients and carbon, except for $\mathrm{Ca}$ (Table 2), which is found in the tree part above the ground, referred as to shoots. On average, wood contains $42 \%$ of N, $45 \%$ of P, $33 \%$ of $\mathrm{K}, 34 \%$ of $\mathrm{Ca}, 47 \%$ of $\mathrm{Mg}$, and $68 \%$ of carbon stored in plants. Considering that among eucalyptus species, C. citriodora has one of the highest commercial values for sawmills, the extraction of wood (wood + bark) would represent $60 \%$ removal of $\mathrm{N}, 72 \%$ of $\mathrm{P}, 62 \%$ of $\mathrm{K}, 81 \%$ of $\mathrm{Ca}, 78 \%$ of $\mathrm{Mg}$, and $87 \%$ of carbon. Surely, exclusive extraction of wood would reduce the nutrient withdrawal from the forest site.

The nutrient content stored in the tree part above the ground varies greatly, depending on the forest site, genetic material, and age of plants. Notably, the effect of climate, mainly water restriction, impairs the absorption of nutrients, generally leading lower biomass and nutrient contents (Santana et al., 2008).

In Curvelo-MG, where the climate is characterized as tropical humid savanna (AW, according to Köppen) with expressive dry season, Pereira et al. (1984) found immobilized $325.14 \mathrm{~kg} \mathrm{ha}^{-1}$ of N, 68.61 of P, 335.27 of K, 298.72 of Ca, and 142.69 of $\mathrm{Mg}$ in the total aerial biomass in a C. citriodora plantation. Trunk (wood + bark) 
represented about $50 \%$ of $\mathrm{N}, 63 \%$ of $\mathrm{P}, 50 \%$ of $\mathrm{K}, 72 \%$ of $\mathrm{Ca}$, and $64 \%$ of $\mathrm{Mg}$ contained in aerial biomass.

The annual litter production (Table 3) varied during the two years of study; however, the leaf fraction that represented about $50 \%$ of the litter biomass did not change, indicating seasonality due to the bark litter contribution, especially in the first year as a resut of suber detachment, typical of some genera of the Mirtaceae family. Other studies have reported leaf yield of $3.48 \mathrm{Mg} \mathrm{ha}^{-1}$ and total annual litter production of $5.63 \mathrm{Mg} \mathrm{ha}^{-1}$ for E. grandis in northern state of Rio de Janeiro (Cunha et al., 2005) and 11.84 $\mathrm{Mg} \mathrm{ha}^{-1}$ for E. grandis in the state of Rio de Janeiro (Balieiro et al., 2004). While observing litter production from the age of 5.5 years in E. urophylla $\times$ E. globulus plantation up to 9 years, Viera et al. (2014b) found variation in litter production over time. At 9 years, production was $8.50 \mathrm{Mg} \mathrm{ha}^{-1}$.

In February of the first year, the highest litter production occurred, and it was observed that the bark deposition was high during this period, but the same pattern was not observed during the second year. In the second year, the material presented greater variation over time. This litter deposition behavior is possibly associated to climate variations verified by the reduction of rainfall in the second year and probably to temperature variations (Figure 2). For E. grandis at
8 years of age and cultivated in the northern state of Rio de Janeiro, the contribution of leaves was greater in the month of December (Cunha et al., 2005). Therefore, it is, evident that in the southeastern region, the production of litter in eucalyptus is concentrated in the hotter and rainier months (Balieiro et al., 2004; Cunha et al., 2005). In the present study, 76.84\% of litter biomass contribution occurred between September and March. Nevertheless, Corrêa et al. (2014) found higher eucalyptus litter deposition in autumn and lower deposition in summer in the state of Rio de Janeiro.

There was a decrease in nutrient concentration in canopy leaves (cl), leaf fall litter (ll), and forest floor leaf litter (lf), except for Ca (Table 4). Rocha et al. (1978) and Pereira et al. (1984) also identified similar variation in studies with Corymbia citriodora. Thus, there is a pattern in the reduction of the nutrient concentration among photosynthetically active leaves and litter leaves accumulating on the ground.

Most $\mathrm{N}$ and $\mathrm{P}$ contained in newly fallen leaves (leaf fall litter) are not found in decomposing leaves; however, it does not reflect in higher mineralization rate (Table 5). Differences in nutrient concentrations in leaves before senescence and levels observed in forest floor leaf litter may indicate the intensity of the nutrient retranslocation process (biochemical cycling). On the other hand, differences in nutrient concentrations

Table 2. Nutrient contents and relative distribution in different parts of $C$. citriodora trees grown in the mountainous region of the state of Rio de Janeiro, Brazil (Standard errors in parentheses).

\begin{tabular}{cccccccc}
\multirow{2}{*}{ Fraction } & $\mathbf{N}$ & $\mathbf{K}$ & $\mathbf{C a}$ & $\mathbf{M g}$ & $\mathbf{C}$ \\
\cline { 2 - 7 } Leaf & & 2.7 & 35.0 & 26 & 7 & 1,336 \\
& $(37.6)$ & $(1.6)$ & $(20.6)$ & $(15.0)$ & $(3.9)$ & $(786)$ \\
Branch & 64 & 2,5 & 65 & 103 & 17 & 5,883 \\
& $(33.0)$ & $(1.3)$ & $(33.2)$ & $(53.1)$ & $(8.8)$ & $(3,005)$ \\
Bark & 56 & 5.1 & 78 & 317 & 33 & 10,990 \\
& $(12.1)$ & $(1.6)$ & $(18.7)$ & $(43.6)$ & $(7.7)$ & $(1,154)$ \\
Wood & 134 & 8.6 & 88 & 231 & 51 & 39,513 \\
& $(8.1)$ & $(1.1)$ & $(4.9)$ & $(5.6)$ & $(9.7)$ & $(3,371)$ \\
\hline
\end{tabular}

Table 3. Litter production in C. citriodora in the mountainous region of the state of Rio de Janeiro, Brazil.

\begin{tabular}{cccccccc} 
& \multicolumn{7}{c}{ Fraction } \\
\hline \multirow{2}{*}{ Year } & Leaf & Branch & Bark & $\begin{array}{c}\text { Flower and } \\
\text { fruits }\end{array}$ & Residue & Total \\
\cline { 2 - 8 } & & \multicolumn{2}{c}{$\mathbf{M g ~ h a}^{-1}$} \\
2000 & 3.22 & 1.17 & 2.09 & 0.43 & 0.13 & 7.04 & 6.12 \\
\hline
\end{tabular}


between produced leaf fall litter and stored forest floor leaf litter indicate the intensity of the biogeochemical cycling process (Reis \& Barros, 1990).

The biochemical P cycling was more intense, and $52.2 \%$ of $\mathrm{P}$ contained in mature leaves were reused before senescence. In contrast to the biochemical cycling efficiency with respect to $\mathrm{N}$ and $\mathrm{P}$, eucalyptus produces relatively poor litter for nutrients that control substrate quality to some extent. In contrast to the biochemical cycling efficiency, in reference to $\mathrm{N}$ and $\mathrm{P}$, nutrients that control, to a certain extent, substrate quality, eucalyptus produces relatively poor litter. Given the results above and others observed by (Drumond et al., 1997), it could be hypothesized that if the plant or stand has high biochemical cycling efficiency, it would be less dependent on the decomposition process (losses by
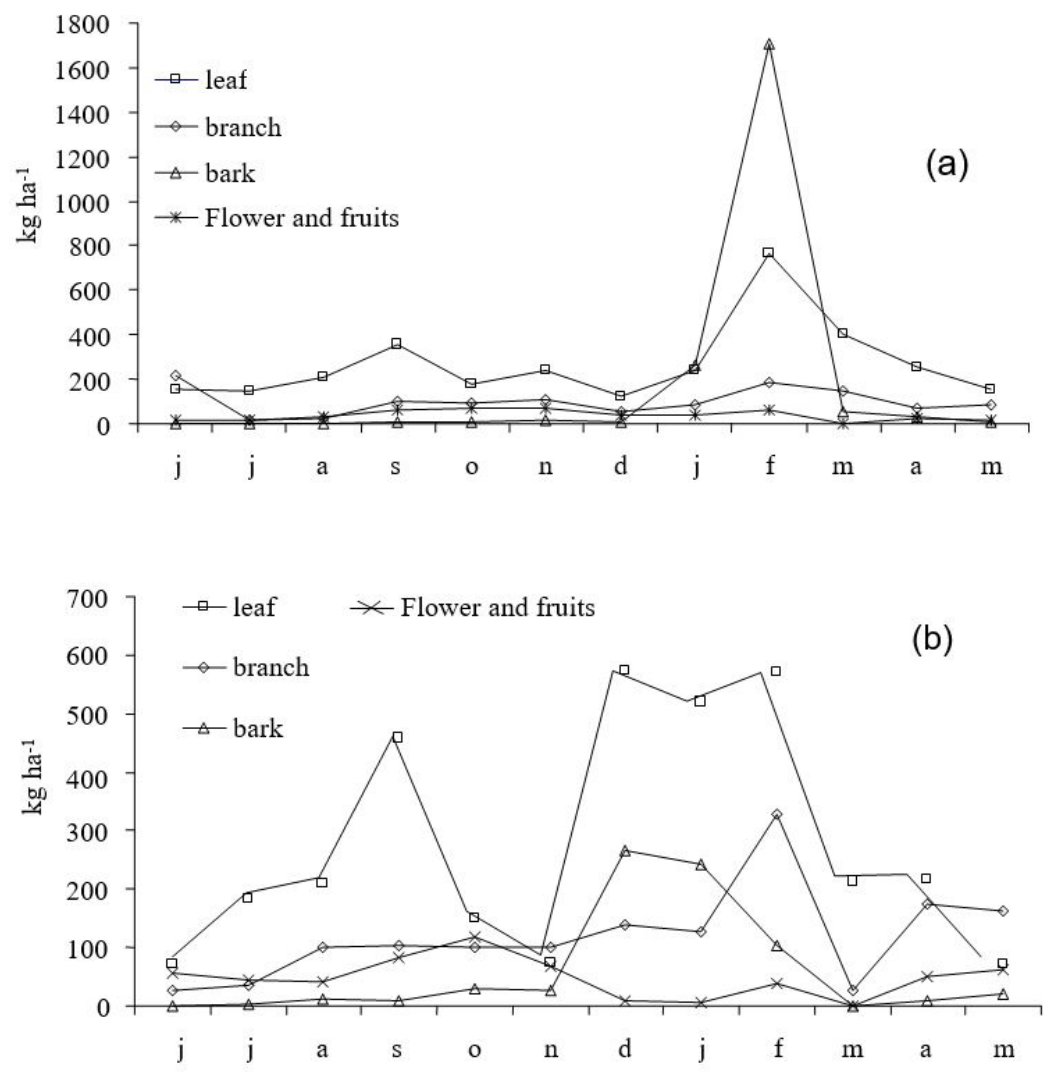

Figure 2. Monthly seasonality between June (j) and May $(\mathrm{m})$ of litter components in C. citriodora in the mountainous region of the state of Rio de Janeiro, Brazil. (a) 2000 and (b) 2001.

Table 4. Nutrient concentration in canopy leaves, leaf fall litter, and forest floor leaf litter. Percentage variation of nutrient content between leaf fall litter (ll) and canopy leaves (cl) and percentage variation between forest floor leaf litter (lf) and leaf fall litter (ll) in C. citriodora in the mountainous region of the state of Rio de Janeiro, Brazil. (Standard errors in parentheses).

\begin{tabular}{cccccc}
\hline \multirow{2}{*}{ Leaf } & $\mathbf{N}$ & $\mathbf{P}$ & $\mathbf{K}$ & $\mathbf{C a}$ & $\mathbf{M g}$ \\
\cline { 2 - 6 } & & & $\mathbf{g ~ k g}^{-1}$ & & \\
canopy & $21.30( \pm 1.06)$ & $0.90( \pm 0.07)$ & $11.66( \pm 0.98)$ & $8.67( \pm 0.69)$ & $2.33( \pm 0.25)$ \\
leaf fall litter & $12.04( \pm 2.62)$ & $0.43( \pm 0.08)$ & $7.28( \pm 0.67)$ & $8.10( \pm 0.82)$ & $1.84( \pm 0.28)$ \\
\hline forest floor & $9.80( \pm 1.96)$ & $0.32( \pm 0.06)$ & $2.51( \pm 0.43)$ & $10.34( \pm 1.09)$ & $1.60( \pm 0.20)$ \\
\hline ll x cl $^{1}$ & -43.5 & -52.2 & -37.5 & -6.6 & -8.5 \\
\hline lf x ll $^{2}$ & -18.6 & -25.5 & -65.5 & +27.6 & -13.0 \\
\hline
\end{tabular}

${ }^{1}\{([11]-[\mathrm{cl}]) /[\mathrm{cl}]\} \times 100 ;{ }^{2}\{([\mathrm{lf}]-[11]) /[11]\} \times 100$. 
energy transfer, volatilization, and leaching). When the decomposition process is imperative for the ecosystem, it is more dependent on biotic and abiotic factors involved in the process. Thus, nutrient reuse depends on the interaction among controlling factors of the decomposition process, and there may be situations of prolonged water deficit that would delay nutrient cycling because it limits the microbiological activity (Turchetto \& Fortes, 2014). From the point of view of internal cycling in eucalyptus, Reis \& Barros (1990) reported that during the decomposition process, there may be immobilization of $\mathrm{N}$, as well as losses due to leaching and reduction of nutrient availability (for example, conversion from labile to non-labile P) from soil to plant. Thus, through biochemical cycling, nutrients are directly used for the growth of new tissues, being a constant source of nutrients for plants. In E. grandis, the magnitude of biochemical cycling was of the order of $-46.3 \%$ for $\mathrm{N}$ and $-48 \%$ for $\mathrm{P}$ (Cunha et al., 2005), which values are very close to those found in the present study. In contrast, the difference in nutrient concentration between leaf fall litter and forest floor leaf litter as an estimate of biogeochemical cycling intensity showed that $\mathrm{K}$ was the nutrient with the highest difference between concentrations at -65.5\%, followed by $\mathrm{P}$ and $\mathrm{N}$. Since $\mathrm{K}$ is not a structural plant element, its transfer by leaching is more intense than other elements (Diniz et al., 2011). By comparison, Ca concentration is relatively higher in residues stored on the soil, as reported by Cunha et al. (2005) and Viera et al. (2014b).

The input of $\mathrm{N}, \mathrm{P}, \mathrm{K}, \mathrm{Ca}$, and $\mathrm{Mg}$ averaged $180.55 \mathrm{~kg} \mathrm{ha}^{-1} \mathrm{yr}^{-1}$ (Table 6). The order for average transfer magnitude was $\mathrm{N}>\mathrm{Ca}>\mathrm{K}>\mathrm{Mg}>\mathrm{P}$. Nutrient intake and the $\mathrm{N}>\mathrm{Ca}$ or $\mathrm{Ca}>\mathrm{N}$ sequence may vary due to the nutritional status and also to the fact that the material returned to the soil. In turn, the nutritional status may vary according to the genetic material (Wadt et al., 1999). Thus, in E. urophylla $\times$ E. globules plantations, the mean order of nutrient supply was $\mathrm{Ca}>\mathrm{N}>\mathrm{K}>\mathrm{Mg}>\mathrm{P}$ with totals of 54.2; 43.6; 18.6; 14.0; $4.1 ; 2.3 \mathrm{~kg} \mathrm{ha}^{-1} \mathrm{yr}^{-1}$, respectively (Viera et al., 2014b), while Cunha et al. (2005) found the sequence to be $\mathrm{N}>\mathrm{Ca}>\mathrm{K}>\mathrm{Mg}>\mathrm{P}$ for $E$. grandis in northern state of Rio de Janeiro.

The contribution of leaves to the transfer of nutrients to the soil was, on average, $57,45,74,42$, and $50 \%$, respectively for $\mathrm{N}, \mathrm{P}, \mathrm{K}, \mathrm{Ca}$, and $\mathrm{Mg}$. This demonstrates the relevance of this fraction for nutrient cycling, as pointed out by Cunha et al. (2005) and Viera et al. (2014b). The average litter biomass stored on the soil was $11.10 \mathrm{Mg} \mathrm{ha}^{-1}$ (Table 5), which is composed of $51 \%$ of leaves. The Ca stock in the litter was higher than that of $\mathrm{N}, \mathrm{P}, \mathrm{K}$, and $\mathrm{Mg}$.

Table 5. Accumulated litter (leaves and total) and nutrient content stored in the forest floor litter of C. citriodora in the mountainous region of the state of Rio de Janeiro, Brazil.

\begin{tabular}{|c|c|c|c|c|c|c|c|}
\hline \multirow{3}{*}{ Year } & \multirow{2}{*}{ Leaf } & \multirow{2}{*}{ Total } & \multicolumn{5}{|c|}{ Nutrients } \\
\hline & & & $\mathbf{N}$ & $\mathbf{P}$ & $\mathbf{K}$ & $\mathrm{Ca}$ & $\mathrm{Mg}$ \\
\hline & \multicolumn{2}{|c|}{ t ha $\mathrm{a}^{-1}$} & \multicolumn{5}{|c|}{$\mathrm{kg} \mathrm{ha}^{-1}$} \\
\hline 2000 & 5.88 & 12.01 & 103.0 & 3.49 & 21.4 & 111.0 & 18.0 \\
\hline 2001 & 5.43 & 10.20 & 87.0 & 2.96 & 18.1 & 94.2 & 15.3 \\
\hline
\end{tabular}

Table 6. Annual production of nutrients in leaf fall litter in C. citriodora in the mountainous region of of the state of Rio de Janeiro, Brazil.

\begin{tabular}{|c|c|c|c|c|c|c|c|c|c|c|}
\hline \multirow{3}{*}{ Fraction } & \multicolumn{2}{|c|}{$\mathbf{N}$} & \multicolumn{2}{|c|}{$\mathbf{P}$} & \multicolumn{2}{|c|}{$\mathbf{K}$} & \multicolumn{2}{|c|}{$\mathrm{Ca}$} & \multicolumn{2}{|c|}{$\mathrm{Mg}$} \\
\hline & \multicolumn{10}{|c|}{ 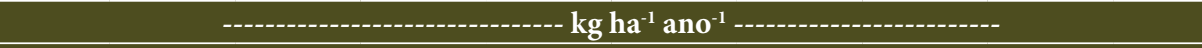 } \\
\hline & 2000 & 2001 & 2000 & 2001 & 2000 & 2001 & 2000 & 2001 & 2000 & 2001 \\
\hline Leaf & 38.8 & 41.8 & 1.4 & 1.4 & 23.5 & 24.1 & 26.1 & 26.8 & 5.9 & 6.1 \\
\hline Branch & 14.5 & 17.5 & 0.2 & 0.2 & 3.7 & 4.5 & 11.8 & 14.3 & 1.4 & 1.7 \\
\hline Bark & 8.4 & 2.9 & 0.8 & 0.3 & 3.7 & 1.1 & 27.7 & 9.0 & 4.2 & 2.0 \\
\hline $\begin{array}{c}\text { Flower and } \\
\text { Fruits }\end{array}$ & 6.7 & 8.6 & 0.4 & 1.3 & 1.0 & 1.2 & 3.2 & 4.3 & 1.0 & 1.4 \\
\hline Residues & 1.7 & 1.2 & 0.1 & 0.1 & 0.6 & 0.4 & 1.0 & 0.9 & 0.1 & 0.1 \\
\hline
\end{tabular}


Litter stock reduction probably occurred in the second year in part due to the lower amount of leaf fall litter (Table 3). Litter stock in E. grandis in northern state of Rio de Janeiro was estimated at $9.56 \mathrm{Mg} \mathrm{ha}^{-1}$ (Cunha et al., 2005), while Viera et al. (2014b) found average of $14.0 \mathrm{Mg} \mathrm{ha}^{-1}$ in E. urophylla $\times$ E. globulus plantations in the state of Rio Grande do Sul, with mean values of $117.4 \mathrm{~kg} \mathrm{ha}^{-1}$ of $\mathrm{N}, 5.1 \mathrm{~kg} \mathrm{ha}^{-1}$ of $\mathrm{P}, 16.9 \mathrm{~kg} \mathrm{ha}^{-1}$ of $\mathrm{K}, 146.8 \mathrm{~kg} \mathrm{ha}^{-1}$ of $\mathrm{Ca}$, and $26.4 \mathrm{~kg} \mathrm{ha}^{-1}$ of $\mathrm{Mg}$.

Based on leaf stock accumulated on the soil, the average leaf decomposition coefficient $\left(\mathrm{K}_{\mathrm{L}}\right)$ was estimated at 0.58 (Table 7 ). Studies by Viera et al. (2014b) indicated variation in the litter decomposition coefficient between 0.47 and 0.61. On the other hand, Cunha et al. (2005) reported litter decomposition coefficients between 0.35 and 0.93 . The authors suggested that this depends on the plot age and the re-growth time, highlighting litter decomposition restriction in E. grandis in in northern state of Rio de Janeiro. Thus, in this settlement, the average residence time of $C$. citriodora litter was 1.68 years, whereas Balieiro et al. (2004) and Schumacher et al. (2013) reported average litter residence time of 1.43 years and 1.33 years in eucalyptus, respectively.

The nutrient mineralization rate was higher for $\mathrm{K}$ (Table 7), notably due to its high solubility in intercellular space (Chapin et al., 2002; Viera et al., 2014a), which favors leaching. Despite the higher Ca content in litter, the mineralization rate was the lowest found among analyzed nutrients, probably because Ca played a structural role in the cell wall (Hawkesford et al., 2012), providing greater recalcitrance of the element to mineralization.

The nutrient distribution for production system components can be observed in Table 8 . The annual litter production varied from 9 to $22 \%$ of N, P, K, Ca, and $\mathrm{Mg}$ for the nutrient capital immobilized in C. citriodora biomass. This indicates that the production of deciduous material considerably contributed to the maintenance of the nutrient stock in the accumulated litter, which acts in a gradual way through the decomposition process in the transfer of nutrients and carbon to the soil.

Due to the soil sampling depth, most nutrients of the soil-plant system are stored at these depths, however, vegetation is the most vulnerable portion because nutrients and carbon that are immobilized in the biomass can be removed from the system through harvest, which results in nutrient extraction and risk of fire. Gatto et al. (2010) evaluated the carbon stock in both soil and biomass of eucalyptus plantations and found that more than half of the system carbon accumulated in the soil, while in wood, stocks are about $29 \%$ of the total carbon. In eucalyptus citriodora, tree biomass comprises $36 \%$ of the total carbon (Table 8 ).

Table 7. Litter decomposition rate $\left(\mathrm{K}_{\mathrm{L}}=\right.$ annual production of leaf fall litter/annual average of forest floor leaf litter) and mineralization rate $\left(\mathrm{K}_{\mathrm{E}}=\right.$ nutrient supply in leaf fall litter / nutrient content in forest floor leaf litter $)$ of $C$. citriodora in the mountainous region leaf fall litter, Brazil.

\begin{tabular}{|cccccccc}
\multirow{2}{*}{ Year } & $\mathbf{K}_{\mathrm{L}}$ & $\mathbf{N}$ & $\mathbf{P}$ & $\mathbf{K}$ & $\mathbf{C a}$ & $\mathbf{M g}$ \\
\cline { 3 - 8 } & & $\mathbf{N}$ & 0.85 & 1.59 & 0.43 & 0.63 \\
2001 & 0.55 & 0.67 & 0.81 & 1.77 & 0.48 & 0.70 \\
\hline
\end{tabular}

Table 8. Nutrient and carbon distribution in tree, forest floor litter, leaf fall litter, and soil in C. citriodora in the mountainous region of the state of Rio de Janeiro, Brazil.

\begin{tabular}{|c|c|c|c|c|c|c|}
\hline & $\mathbf{N}$ & $\mathbf{P}$ & $\mathbf{K}$ & $\mathbf{C a}$ & Mg & C \\
\hline \multicolumn{7}{|c|}{$\longrightarrow \mathrm{kg} \mathrm{ha}^{-1} \longrightarrow$} \\
\hline Tree & $318(77 \%)^{1}$ & $19(86 \%)$ & $266(93 \%)$ & $677(87 \%)$ & $108(86 \%)$ & $57,772(92 \%)$ \\
\hline $\begin{array}{l}\text { Stored in litter } \\
\text { forest floor }\end{array}$ & $95(23 \%)$ & $3(14 \%)$ & $20(7 \%)$ & $102(13 \%)$ & $17(14 \%)$ & $5,111(8 \%)$ \\
\hline Leaf fall litter & $71(22 \%)^{2}$ & $3(16 \%)$ & $32(12 \%)$ & $63(9 \%)$ & $12(9 \%)$ & - \\
\hline Soil $(80 \mathrm{~cm})$ & $6,998(94 \%)^{3}$ & $30(55 \%)$ & $491(61 \%)$ & $1,087(56 \%)$ & $283(67 \%)$ & 95,020 \\
\hline
\end{tabular}

${ }^{1}$ Percentage in relation to the stock in vegetation plus litter; ${ }^{2}$ Percentage of annual production in relation to stock in vegetation; ${ }^{3}$ Percentage in relation to the total nutrient stock in the system. 


\section{CONCLUSION}

Of the total nutrients in the biomass, 71, 3, 32, 58, and $12 \mathrm{~kg} \mathrm{ha}^{-1}$ for $\mathrm{N}, \mathrm{P}, \mathrm{K}, \mathrm{Ca}$, and $\mathrm{Mg}$, respectively, were returned by the litter. This demonstrates the importance of the nutrient cycling process for maintaining the productive capacity of the environment.

As the most labile fraction in the decomposition process, leaves transferred more than $50 \%$ of nutrients to the soil, as compared to the other litter constituents.

The retranslocation of nutrients from leaves before senescence contributes to reduce the $\mathrm{N}$ and $\mathrm{P}$ concentration in litter accumulated on the soil.

The Corymbia citriodora long-rotation nutrient cycling process represents an important strategy for maintaining productivity of the forest site.

\section{SUBMISSION STATUS}

Received: 20 feb., 2017

Accepted: 14 feb., 2018

\section{CORRESPONDENCE TO}

\section{Gláucio Mello Cunha}

Departamento de Biologia, Universidade Federal do Espirito Santo - UFES, Alto Universitário, CEP 29500-000, Alegre, ES, Brasil e-mail: gláucio.cunha@ufes.br

\section{REFERENCES}

Amorim HB, Francelino MR, Salamene S, Pedreira LOL, Assunpção LI Fo, Capitano RC et al. Estimativa da área ocupada por reflorestamentos no estado do Rio de Janeiro. Cerne 2012; 18(1): 27-32. http://dx.doi.org/10.1590/ S0104-77602012000100004.

Anderson JD, Ingram JSI. Tropical soil biology and fertility: a handbook of methods. 2. ed. Wallingford: $\mathrm{CAB}$ International; 1996. $221 \mathrm{p}$.

Balieiro FC, Franco AA, Pereira MG, Campello EFC, Dias LE, Faria SM et al. Dinâmica da serapilheira e transferência de nitrogênio ao solo em plantios de Pseudosamanea guachapele e Eucalyptus grandis. Pesquisa Agropecuária Brasileira 2004; 39(6):597-601. http://dx.doi.org/10.1590/ S0100-204X2004000600012.

Chapin FS 3rd, Matson PA, Mooney HA. Principle of terrestrial ecosystem ecology. New York: Springer-Verlag; 2002.
Corrêa TA No, Dos Anjos LHC, Pereira MG, Jaccoud CSF. Aporte de serapilheira em plantios de eucalipto em função da qualidade do sítio. Pesquisa Florestal Brasileira 2014; 34(80): 399-406.

Cunha GM, Gama-Rodrigues AC, Costa GS. Ciclagem de nutrientes em Eucalyptus grandis W. Hill ex Maiden no Norte Fluminense. Revista Árvore 2005; 29(3): 353-363. http://dx.doi.org/10.1590/S0100-67622005000300002.

Diniz AR, Pereira MG, Loss A. Aporte de material decíduo para o solo em plantio de eucalipto e floresta secudária. Pesquisa Florestal Brasileira 2011; 31(65): 19-26. http:// dx.doi.org/10.4336/2011.pfb.31.65.19.

Drumond MA, Barros NF, Souza AL, Silva AF. Distribuição de biomassa e de nutrientes em diferentes coberturas florestais e pastagem na região do Médio Rio Doce-MG. Revista Árvore 1997; 21: 187-199.

Empresa Brasileira de Pesquisa Agropecuária - EMBRAPA. Manual de métodos de análise de solo. 2. ed. Rio de Janeiro: CNPS; 1997. $212 \mathrm{p}$.

Ferreira M. Melhoramento e a silvicultura intensiva clonal. Revista IPEF 1992; 45: 22-30.

Fonseca S, Barros NF, Novais RF, Leal PGL, Loures EG, Moura W Fo. Alterações em um latossolo sob eucalipto, mata natural e pastagem II. Propriedades orgânicas e microbiológicas. Revista Árvore 1993; 17(3): 289-302.

Gama-Rodrigues AC, Gama-Rodrigues EF, Barros NF. Balanço de carbono e nutrientes em plantio puro e misto de espécies florestais nativas no sudeste da Bahia. Revista Brasileira de Ciência do Solo 2008; 32(3): 1165-1179. http://dx.doi.org/10.1590/S0100-06832008000300025.

Gatto A, Barros NF, Novais RF, Silva IR, Leite HG, Leite FP et al. Estoque de carbono no solo e na biomassa em plantações de eucalipto. Revista Brasileira de Ciência do Solo 2010; 34(4): 1069-1079. http://dx.doi.org/10.1590/ S0100-06832010000400007.

Gatto A, Bussinguer AP, Ribeiro FC, Azevedo GB, Bueno $\mathrm{MC}$, Monteiro MM et al. Ciclagem e balanço de nutrientes no sistema solo-planta em um plantio de Eucalyptus sp., no Distrito Federal. Revista Brasileira de Ciência do Solo 2014; 38(3): 879-887. http://dx.doi.org/10.1590/S010006832014000300019 .

Hawkesford M, Horst W, Kichey T, Lambers H, Schjoerring J, Møller IS et al. Functions of macronutrients. In: Marschner P, editor. Marschner's mineral nutrition of higher plants (3rd ed). San Diego: Academic Press; 2012. http://dx.doi. org/10.1016/B978-0-12-384905-2.00006-6.

Instituto Brasileiro de Geografia e Estatística - IBGE. Produção da extração vegetal e da silvicultura [online]. Rio de Janeiro: IBGE; 2014 [cited 2015 July 1]. Available from: http://www.ibge.gov.br/home/estatistica/economia/ pevs/2014/default_ods.shtm

Laclau J-P, Ranger J, Gonçalves JLM, Maquère V, Krusche $\mathrm{AV}, \mathrm{M}$ 'Bou AT et al. Biogeochemical cycles of nutrients in 
tropical Eucalyptus plantations main features shown by intensive monitoring in Congo and Brazil. Forest Ecology and Management 2010; 259(9): 1771-1785. http://dx.doi. org/10.1016/j.foreco.2009.06.010.

Olson JS. Energy storage and the balance of producers in ecological systems. Ecology 1963; 44(2): 322-331. http:// dx.doi.org/10.2307/1932179.

Paes FASV, Lima AMN, Hakamada RE, Barros NF. Impacto do manejo dos resíduos da colheita, do preparo do solo e da adubação na produtividade de eucalipto. Revista Brasileira de Ciência do Solo 2013; 37(4): 1081-1090. http://dx.doi.org/10.1590/S0100-06832013000400025.

Pereira AR, Andrade DC, Leal PGL, Teixeira NCS. Produção de biomassa e remoção de nutrientes em povoamentos de Eucaliptus citriodora e Eucaliptus saligna cultivados na região do cerrado de Minas Gerais. Revista Floresta 1984; 15(12): 8-16.

Reis MGF, Barros NF. Ciclagem de nutrientes em plantios de eucalipto. In: Barros NF, Novais RF, editors. Relação solo-eucalipto. Viçosa: Folha de Viçosa; 1990.

Rocha Fo JV, Haag HP, Oliveira GD, Pitelli RA. Ciclagem de nutrientes em florestas implantadas de Eucalyptus e Pinus I. distribuição no solo e na manta. Anais da Escola Superior de Agricultura Luiz de Queiroz 1978; 30: 113-123. http://dx.doi.org/10.1590/S0071-12761978000100008.

Sant’Anna JL No. Decálogo da climatologia do sudeste brasileiro. Revista Brasileira de Climatologia 2005; 1(1): 43-60.

Santana RC, Barros NF, Novais RF, Leit HG, Comerford NB. Alocação de nutrientes em plantios de eucalipto no Brasil. Revista Brasileira de Ciência do Solo 2008; 32(spe): 2723-2733. http://dx.doi.org/10.1590/S010006832008000700016 .
Schumacher MV, Corrêa RS, Viera M, Araújo EF. Produção de serapilheira em um povoamento de Eucalyptus urophylla x Eucalyptus globulus maidenii. Cerne 2013; 19(3): 501-508. http://dx.doi.org/10.1590/S0104-77602013000300018.

Tedesco MJ, Volkweiss SJ, Bohnen H. Análises de solo, plantas e outros materiais. Porto Alegre: UFRGS; 1985. 50 p. (Boletim Técnico, no. 5).

Teixeira JL, Barros NF, Costa LM, Campos JCC, Leal PGL. Biomassa e conteúdo de nutrientes de duas espécies de eucalipto em diferentes ambientes do Rio Doce, MG. Revista Árvore 1989; 13(1): 20-34.

Turchetto F, Fortes FO. Aporte e decomposição de serapilheira em Floresta Estacional Decidual na região do Alto Uruguai, RS. Pesquisa Florestal Brasileira 2014; 34(80): 391-397. http://dx.doi.org/10.4336/2014.pfb.34.80.735.

Viera M, Schumacher MV, Araujo EF. Disponibilização de nutrientes via decomposição da serapilheira foliar em um plantio de Eucalyptus urophylla $\times$ Eucalyptus globulus. Floresta e Ambiente 2014a; 21(3): 307-315. http://dx.doi. org/10.1590/2179-8087.066313.

Viera M, Schumacher MV, Araujo EF, Correa RS, Caldeira MVW. Deposição de serapilheira e nutrientes em plantio de Eucalyptus urophylla $\times$ E. globulus. Floresta e Ambiente 2014b; 21(3): 327-338. http://dx.doi.org/10.1590/21798087.053913 .

Vilas Bôas O, Max JCM, Melo ACG. Crescimento comparativo de espécies de Eucalyptus e Corymbia no município de Marília, SP. Revista Instituto Florestal 2009; 21(1): 63-72.

Wadt PGS, Novais RF, Alvarez VH, Barros NF, Dias LE. Variações no estado nutricional de eucaliptos em função do material genético e da idade da árvore. Pesquisa Agropecuária Brasileira 1999; 34(10): 1797-1803. 